Article

\title{
The Strategy of Ontological Negativity in Meister Eckhart's Metaphysics and in Philosophical Traditions of India
}

\author{
Tatyana Lifintseva * and Dmitry Tourko * \\ Faculty of Humanities, School of Philosophy, National Research University Higher School of Economics, \\ Staraya Basmannaya st., 21/4, Moscow 105066, Russia \\ * Correspondence: lifintsevatanya64@gmail.com (T.L.); tourko.dmitry@gmail.com (D.T.); \\ Tel.: +7-9099748119 (T.L.)
}

Received: 4 October 2018; Accepted: 20 November 2018; Published: 26 November 2018

\begin{abstract}
In this article, the authors investigate ontological strategies in Meister Eckhart's metaphysics, which remounts Neoplatonism and the Corpus Areopagiticum, and in two schools of Indian philosophical tradition, the Advaita Vedanta and Early Buddhism. Along with differences in the anthropology, epistemology, and soteriology of these traditions, we can find similar strategies of ontological negativity and mystical experience in both traditions: detachment from the world of images and forms as the highest blessing; non-association of oneself with corporality, feelings, cognitive ability and reason; interiorizing the intentionality of consciousness, and termination of its representative function. Practically all systems of Indian philosophy were projects of liberation or personal transformation from subjugation and suffering into being free and blissful. The idea of spiritual release is also the cornerstone of Christian salvation as with the renouncement of sin and entering blissful unity with God. The apophatic doctrine of Christian neo-platonic mystics about the concealment, non-comprehensiveness, and inexpressibleness of God as the One and Nothingness, and also the idea of comprehension of God by means of detachment from the created world and one's own ego, gives us the opportunity for such comparative analysis.
\end{abstract}

Keywords: Meister Eckhart; detachment; mysticism; Advaita Vedanta; Buddhism; Neoplatonism; Dionysius the Areopagite; Śankara; nothingness; negativity

\section{Introduction}

Eckhart's doctrine has been investigated and interpreted in many aspects, including its comparison with the philosophical traditions of India, China, and Japan. D. T. Suzuki's 1957 book "Mysticism: Christian and Buddhist" ${ }^{1}$ was probably the first major work specifically juxtaposing Eckhart's mysticism and Buddhism, mostly in its Japanese interpretation. In it, the scholar emphasizes Eckhart's uniqueness as a Christian author and draws parallels between Eckhart's Gottheit and Tao of Lao-tsu, Eckhart's detachment and Mahayana's emptiness (Śūnyatā). Suzuki asserts that Eckhart's views were "singularly Mahayanistic". Another early study seeking to contrast and reconcile Eckhart's mystical anthropology and Zen Buddhism was Sh. Ueda's German-language book on the subject, first published in $1965 .^{2}$ J. Politella ${ }^{3}$ quoted the Tamil philosopher Ananda K. Coomaraswamy, who equated Eckhart's ideas "with the basic philosophy of the Vedas, Manu, and the Bhagavad-gita"

\footnotetext{
(Suzuki 2002)

(Ueda 2018).

(Politella 1965).
} 
and suggested using Eckhart "as a bridge between Hindu and Christian thought". J. Milne ${ }^{4}$ wrote that Eckhart's mysticism and vedantic non-duality "throw light" upon one another, i.e., should be subject to fruitful comparative study. R. Shah-Kazemi explored three different strategies of mystical ascension in "Paths to Transcendence: According to Shankara, Ibn Arabi, and Meister Eckhart" . In his book, he maintains that the essence of Eckhart's teachings may be summed up in "the Birth of the Word in the soul". The Birth is both a criterion of all spiritual practices and a summit of the direct experience of transcendence. L. Holt ${ }^{6}$ undertook a daring attempt to explore Eckhart's thought through the lens of the Bhagavad Gita. H.-S. Keel ${ }^{7}$ went so far as to state that Eckhart's thought could remove the dichotomy between Christianity and the Asian religions and serve as a point of convergence between Christian mysticism and Eastern spirituality. C. Zuijderhoudt ${ }^{8}$ stressed similarities between Eckhartian mysticism and Advaita in that both are viewed as paths to direct liberation and achieving one's true nature. J. Joseph ${ }^{9}$ endeavoured to draw a comparison between Eckhart's Godhead (Gottheit) and the Buddha-nature of Mahayana. Michael A. Sells in his "Mystical Languages of Unsaying"10 convincingly demonstrated that apohasis functions as a "cross-cultural mode of discourse". Sells's work specifically points out similarities and common points in respective doctrines of Plotinus, Islamic authors, and Meister Eckhart. Nevertheless, in those studies, the connection of Eckhart's doctrine with the Corpus Areopagiticum remounting of Neoplatonism was almost not demonstrated, while this very connection provides the possibility to compare Eckhart with philosophical traditions of India-Advaita-Vedanta and early Buddhism, in this case.

If there are similarities between the strategies of negativity employed by neo-platonists, Pseudo-Dionysius and Meister Eckhart on the one hand, and Buddhist and Vedic traditions, on the other hand, far-reaching conclusions about the nature of human spirituality can be made. In many strains of thought in different epochs, the mind's urge to go beyond the constraints of rationality has emerged as its self-restriction. How could a mystic or philosopher touch upon something totally inexpressible in lay terms, alien to the human mode of thinking, lying beyond all conception? All words and descriptions fail to approach this task. Therefore, the only applicable strategy is to use language and logic against themselves. This paper argues that such negativity is a universal strategy found in diverse religious traditions.

The authors do not find themselves within either Christian or Indian traditions. However, we are aware that it is impossible to explore a cultural or religious matter from an entirely neutral point of view. There is also a problem of representation and colonising the other by those who do not belong to the culture in question. There are always unconscious presuppositions and restrictions imposed on us by the language we use. Nevertheless, we will attempt to deliver our comparison in an entirely uninterested and neutral manner.

\section{Negation and the Uniform Reality}

The connection of Eckhart's doctrine with writings of Dionysius (Pseudo-Dionysius) the Areopagite ("Corpus Areopagiticum") does not raise doubts-we find more than 20 references to Areopagite in Eckhart's sermons. Pseudo-Dionysius was an anonymous Christian theologian, mystic and philosopher who attributed his doctrine to the $1 \mathrm{c}$. CE Christian saint Dionysius the Areopagite. Modern scholars date Pseudo-Dionysius's works to not earlier than first decades of 6 c. CE. Dionysius's doctrine, which united a number of major neo-platonic lines, especially Proclus (412-485)

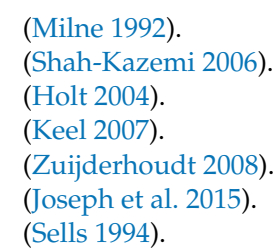


and Porphyry (c. 234-c. 305), as well (of course) as Plato and early Christian Patristics, formed a focus in which Antique and Christian elements were crossed and became a source of many theological and philosophical concepts important to the Middle Ages and the Renaissance.

The indisputable influence of the Areopagitic ideas can be found in John of Damascus (c. 675-c. 749), John Scotus Eriugena (c. 815-c. 877), Thomas Aquinas (1225-1274), Gregory Palamas (c. 1296-c. 1357 or 1359), Maximus the Greek (c. 1475-1556), and many other thinkers. And, certainly, it can be found in German mysticism, which might as well be called "Eckhart's tradition"—including the writings of John of Ruusbroec (1293 or 1294-1381), Heinrich Suso (1295-1366), Johannes Tauler (c. 1300-c. 1361), Jakob Böhme (1575-1624), and Angelus Silesius (1624-1677).

As implied above, among those who call upon these ideas, Meister Eckhart (c. 1260-c. 1328) is the most prominent. Eckhart references Dionysius when he deals with the key subjects of his own doctrine: God has neither image nor resemblance; the soul which has been liberated from all creation incorporates God; detachment as a condition of the highest blessing; the need to approach God with unseeing eyes; God as Nothingness.

We will try to compare the ideas of the mystic-apophatic theology of Eckhart and philosophical traditions of India-the darśana Advaita Vedanta and early Buddhism. This task is rather difficult, as it is always easy to give in to the temptation to underline only a certain external similarity. We realize that in Christian and Indian (Vedic and Buddhist, in this case) traditions there are different anthropologies, different cognitive and soteriological purposes, and even different ontological bases. Still, the ideas of Meister Eckhart, which exist to a large extent on the margin of classical Western thought, offer the possibility for such a comparative study.

Over several past decades, there have been ongoing disputes if the terms "mystic" and "mysticism" are relevant when applied to the spiritual traditions of India and China. These disputes have continued since the second half of the $19 \mathrm{c}$., when theosophists (and later anthroposophists) naively attempted to unify all kinds of mystical experience and reduce it to some common ground.

Perhaps the first prominent scientific work on comparative mysticism was Rudolf Otto's "Mysticism East and West: A Comparative Analysis of the Nature of Mysticism" (first published in 1926). Otto's thought influenced the phenomenology and psychology of religion, theories of religious symbolism and studies of the category of the holy. He was greatly interested in Indian-Christian comparativism and wrote a commentary on the Bhagavad Gita, among other works. In "Mysticism East and West", Otto opposes theosophic attempts of unification, instead arguing for core differences in respective concepts of "God" and the mystical visions of Shankara and Eckhart:

"Sankara's Brahman is sat, chit, and chaitanyam; is Being and Spirit through and through, utterly opposed to all "deafness" (jada) and all matter. No one can deny the lofty spirituality of this conception of God. But the difference between this and Eckhart's conception is at once palpable if the question is asked: Is this Brahman a living God? (Otto 2016, p. 169)

and

This [Eckhart's] God is in Himself a living process, not a static Being. (Otto 2016, p. 170)

The book consists of two parts, one of which deals with similarities between the two mystics, the other with differences. Otto concludes: "In spite of great formal equalities, the inner core of Eckhart is as different from that of Sankara as the soil of Palestine and of Christian Gothic Germany in the thirteenth century is different from that of India" (Otto 2016, p. 168).

Otto describes two initial intuitions that lead to the development of two distinct mystical ways: "the Way of Introspection" and "the Way of Unifying Vision". The first way urges a mystic to withdraw from all outward things and focus on the depths of their own self, not the world. The second way strives to realize Unity of Being in its "struggle against all diversity". The two ways could be thought of as "mutually exclusive and antagonistic". However, according to Otto, Shankara and Eckhart blend together both ways. 
We suppose that the term "mysticism" implies the opposition "reason-faith" or "reason-intuition" or even "rational-irrational". And it is quite clear that this opposition was introduced by the European (or Mediterranean) civilization which begot the very concept of "mysticism". There were many reasons for that; the most important is the contradiction which was initially present in the Christian culture between its Antique and Judaic sources, between "Athens and Jerusalem", as Tertullian wrote. For a Western mentality, it is almost obvious that mysticism divides being into two regions and suggests that we should "break through" into the region of "true being". Huge difficulties arise when one attempts to impose such a scheme onto, say, Buddhist, Vedic, or Taoist ways of thinking. The problem is that the idea of a transcendent God, and the transcendent reality in general, is expressed most explicitly in monotheist (Abrahamic) religions, which perceive the Divine as super-natural-the Creator, the Almighty, the Providence; God the Goodness, Truth, and Beauty (Christianity). Therefore, the mode of action inherent in Western mysticism is transcending into something true and "highest" and withdrawal from everything "low" and false. But, for example, the great Hindu philosopher and religious reformer Shankara (788-820 CE), the founder of the Indian school Advaita Vedanta ("knowledge of the non-duality"), wrote that all "judgments of distinction", whether they be between (the terms are, certainly, from the Western classical tradition) immanent and transcendent, spirit and nature, consciousness and matter, subject and object, thinking and being, truth and lie, sublime and low, fine and ugly, as well as all other binary oppositions-all in essence are merely the fruit of "ignorance" (a-vidya), which splits the uniform reality into two and represents the diverse sensual world (maya) as something having its own being (svabhava). However, the rejection of and ability to move beyond the veil of maya and attaining awareness of its illusory nature demanded both the most powerful and strict philosophical discourse and meditative yogic practice.

Within the tradition of Christian apophatic theology, there is an idea of leaving the empirical world for the sphere of Nothingness, from the sphere of images to "the imageless". A human, according to Eckhart, consists of the external and internal persons. The external person is comprised of five feelings (sight, hearing, touch, sense of smell, taste) which borrow their energy from the soul and are receptive of the created world. Such knowledge happens by virtue of images which only refer to things, yet are not things themselves. In creations and images, there is no bliss, perfect bliss is found only in God. Besides, the soul cannot know itself by means of intermediaries and images, for they are not inside of it. Eckhart insists on thorough departure from the external person, which is closely connected to created entities, in favor of the internal person where resides the most intimate-what is "detached from time and space and from all that has any hankering or taste for the things of time and space, having nothing in common with anything" (Eckhart 2009, p. 526).

The major ontological, anthropological, and ethical category in Eckhart's doctrine is detachment. Detachment, according to Eckhart, is more important than other virtues, even love, as it brings the person closer to the Deity than other virtues do. Detachment makes one akin to God, immovable and unaffected by things. Detachment is not the purpose in itself; the purpose is God, but only having liberated itself through detachment can the internal person rise above the external one. Having done that, the soul provides the external person with no more energy than it is required for keeping the body alive. According to Eckhart,

Only pure detachment surpasses all things, for all virtues have some regard to creatures, but detachment is free of all creatures. [ ... ] You should know that true detachment is nothing else but a mind that stands unmoved by all accidents of joy or sorrow, honour, shame, or disgrace, as a mountain of lead stands unmoved by a breath of wind. This immovable detachment brings a man into the greatest love to God. [ ... ] You must know that to be empty of all creatures is to be full of God. (Eckhart 2009, pp. 566-67)

The concept of "detachment" in Eckhart (German: Abgeschiedenheit, Gelassenheit) contains connotations of excision, cutting off, escape, leaving. Such a "devastated" consciousness is best prepared for perceiving the highest reality. Here we can also recall the neo-platonic formula offered by Plotinus, "afele panta" (forsake everything). 
The introspective pathos of Eckhart's homilies reminds one of the ethe of self-knowledge which permeates philosophical doctrines of India. The abnegation of the world of forms, rupa loca, is present in both Vedic and Buddhist traditions. Such liberation is achieved via mental concentration, interiorizing the mind's intentionality, averting the senses from "external" objects and suspending the formation of representations. As for philosophical schools of India, it is possible to cite a few, both Vedic and Buddhist ones. In "Katha-Upanishad" (one of the earliest poetic Upanishads) it is said:

When every desire that harboureth in the heart of a man hath been loosened from its moorings, then this mortal putteth on immortality; even here he enjoyeth Brahman in this human body.

The Purusha, the Spirit within, who is no larger than the finger of a man is seated forever in the heart of creatures; one must separate Him with patience from one's own body as one separates from a blade of grass its main fibre. Thou shalt know Him for the Bright Immortal, yea, for the Bright Immortal. (Aurobindo 2006, pp. 126-27)

Nagarjuna (2nd century CE), an "ontological nihilist" or in Western terms, sceptic, is famous as the most radical and consistent Mahayana philosopher, who strived to demonstrate the inherent emptiness (sunyata) of all metaphysical notions and concepts (such as consciousness, God, causality, time, space, etc.) via his method of "negative dialectics".

Initially, it was extremely difficult for European researchers to conceive Nagarjuna's nihilism and scepticism. In "The Idea of the Holy" (originally published in 1917) Rudolf Otto wrote:

But what is true of the strange 'nothingness' of our mystics holds good equally of the "sunyam" and the "sunyata," the "void" and "emptiness" of the Buddhist mystics. This aspiration for the "void" and for becoming void, no less than the aspiration of our western mystics for "nothing" and for becoming nothing, must seem a kind of lunacy to anyone who has no inner sympathy for the esoteric language and ideograms of Mysticism, and lacks the matrix from which these come necessarily to birth. To such a one, Buddhism itself will be simply a morbid sort of pessimism. But in fact, the "void" of the eastern, like the "nothing" of the western, mystic is a numinous ideogram of the "wholly other". (Otto 1923, p. 30)

The Buddhist concept of "sunya" refers to the idea of lack of substance in things, relativity of all things, interdependency, co-correlativity of elements that constitute the world. This category acts first and foremost as a remedy: it is meaningless to be attracted to anything as long as nothing exists on its own (svabhava). Accordingly, the concept of sunya contains nothing sacred or numinous (unlike in Otto's interpretation). The feeling of awe, which for Otto constitutes the core of religious experience, could not be applied to non-theistic religions. While accepting the traditional Hindu pantheon and adding new "deities" to it, Buddhists and Jains never perceived gods as numinous. The founders of these religions were considered much more "transcendent" that any kind of deity. Furthermore, in the two traditions, the very idea of God the Creator was criticized, sometimes even sarcastically, for instance, as a memory lapse of ascetics who delved too far into their past lives. A quote ascribed to Nagarjuna goes as follows:

One variety of exercises in concentration consists of choosing some kind of a landscape, a garden for instance, as a subject of meditation. First, the student examines the garden, observing every detail. The flowers, their different species, the way in which they are grouped, the trees, their respective height, the shape of their branches, their different leaves and so on, noting all particulars that he can detect. When he has formed a subjective image of the garden, that is to say when he sees it as distinctly when shutting his eyes as when looking at it, the disciple begins to eliminate one by one the various details which together constitute the garden. Gradually, the flowers lose their colours and their forms, they crumble into tiny 
pieces which fall to dust and finally vanish. The trees, also, lose their leaves, the branches shorten and seem to be withdrawn into the trunk. The latter grows thin, becomes a mere line, more and more flimsy till it ceases to be visible. Now, the bare ground alone remains and from it, the novice must subtract the stones and the earth. The ground in its turn vanishes ... It is said that by the means of such exercises one succeeds in expelling from the mind all idea of form and matter and thus gradually reaches the various states of consciousness such as that of the "pure, boundless space," and that of the "boundless consciousness." Finally one attains to the "sphere of the void," and then to the sphere where "neither consciousness nor unconsciousness" is present. (David Neel 1937, p. 249-50)

The next step after the abandonment of the empirical world with its forms and images is to surrender and leave behind all the conditions of your own mentality and mind. Śankara's treatise "Atma Bodha" ("Atman's Awakening") begins with a statement that only knowledge leads to liberation. The knowledge in question here is the knowledge of one's own nature-refusal to associate oneself with corporality, feelings, cognitive abilities, and reason. By separating "the internal pure Atman", an impersonal spirit present in the personal Ego from the three upadhas (corporality, empirical soul, and ignorance), a yogi endures a mystical "rising" of Atman as the source of being, thought, and bliss (sat, cit, ananda).

However, there are a number of theoretical problems here. Indian (Vedic and Buddhist) and Western (neo-platonic and Christian) ontologies are formed on absolutely different bases and therefore, it seems, are not subject to comparison at all. Besides, we aware that there are strict differences between Budhhist ontologies of the substrateless process and Vedic ontologies of substantivism. However, in both Vedic philosophy and Buddhism, the empirical (sansaric) subject is considered an illusion. In the Vedic religion, the individual mentality (soul, jiva) is described as a thin body (thin, but still a body), as a false receptacle, a peel for Atman. Here we can see a radical difference of Vedic and Buddhist metaphysics (in particular, that of Advaita Vedanta) from the metaphysics of the created personality: for example, Christian theism postulates that a person possesses a single body (physical) with its individual and unique characteristics, as well as the one and only soul with a unique way of communication between said body and soul. Therefore, in the doctrine of Advaita Vedanta about the mentality-body, the mentality as just a cover for something else, the highest, assuming that consciousness has to belong to this cover, is opposite not only to Christian, but almost any Western philosophical concept of personal being. Nevertheless, some ideas in Christian mysticism which trace back to Neoplatonism provide an opportunity for a comparative analysis.

The Buddhist Sutta-Pitaka (Udana I, Bodhi-sutta III) is the second part of the threefold collection Tipitaka which is attributed to Buddha and his closest associates. It is recognized (with rare exceptions) in all schools of hīnayāna and mahayāna. In our opinion, the following quote illustrates the technique of destroying empirical subject's attachments in a brilliant, expressive, and strictly consecutive way:

From the cessation of ignorance comes the cessation of fabrications.

From the cessation of fabrications comes the cessation of consciousness.

From the cessation of consciousness comes the cessation of name-and-form.

From the cessation of name-and-form comes the cessation of the six sense media.

From the cessation of the six sense media comes the cessation of contact.

From the cessation of contact comes the cessation of feeling.

From the cessation of feeling comes the cessation of craving.

From the cessation of craving comes the cessation of clinging/sustenance.

From the cessation of clinging/sustenance comes the cessation of becoming.

From the cessation of becoming comes the cessation of birth.

From the cessation of birth, then ageing-and-death, sorrow, lamentation, pain, distress, and despair all cease. Such is the cessation of this entire mass of suffering \& stress. (Bhikkhu 2012, pp. 28-29) 
Let us now consider Eckhart's theology, which in his time was deemed heresy. He postulates that Deity (Gottheit) is immovable, non-acting, indefinable and inexpressible. Not only does it generate all creation, including the human soul, but also the Holy Trinity (Gott). Eckhart's God, unlike the Deity, moves, acts and begets the world. Being transcendent to the created world, God nevertheless is not identical to the Deity. As God the Father, God the Son, and God the Holy Spirit are only persons of the One God distinguished by human reason, God is only an image of the Deity. Human beings can comprehend God without mystical experience, but this God is not the final soteriological purpose. And it is impossible to conceive the Deity empirically, nor by intellect, nor even by means of devout faith. Dionysius the Areopagite wrote that such knowledge is possible for a person only through detachment and cutting off the imperfect with all one's heart. According to him, the way to the Deity leads to a place where "unchangeable mysteries of heavenly Truth lie hidden in the dazzling obscurity of the secret Silence, outshining all brilliance with the intensity of their darkness, and surcharging our blinded intellects with the utterly impalpable and invisible fairness of glories which exceed all beauty" (Dionysius the Areopagite 1997, p. 118). In order for the soul to give birth to the Deity, according to Eckhart, a person by means of detachment has to be purified from all the created, having become indivisible with the Deity-i.e., to fall into ignorance, silence, gloom, and void, where the Deity which does not have an image will come into contact with the soul. The more a person is free from images, the more they are receptive to God. Casting aside earthly images is ignorance, but this ignorance is higher than the knowledge characteristic of the natural mind. And again-as Dionysius the Areopagite wrote- "And you abandoned your brilliant mind and the knowledge of things for the sake of the Divine night, which must not be named" (Dionisiy 2002, p. 737).

The formation of Christian apophatic theology was profoundly influenced by the neo-platonic doctrine of the One. The One of neo-platonic philosophers is the Absolute, above any definitions, concepts, and categories. It is above all beings, for which it is the source. The One surpasses everything real and it is essentially indescribable, non-semiotic, and inexpressible in language. It is equal to Nothingness. Everything in the world exists only due to participation in the One, but the one itself is ultramundane to anything real. The One is absolutely self-sufficient and does not need anything, even itself. But due to a surplus of itself within itself, it overflows without decreasing, emanates the Intellect (Nous), the World-Soul and the Cosmos. The negative definitions of the Absolute-the One in Plotinus were applied to God in the apophatic theology of Christian neo-platonics. The emanation, according to Plotinus, is cyclic: things not only proceed from the One, but are also capable of going back to it, passing the same steps in reverse order; such an ability is given to the human soul. This idea is the cornerstone of Plotinus's doctrine about the spiritual experience he calls ecstasy. Ecstasy is transcendence beyond the limits of sensual space and subjective limitation, it is "being-out-of-itself". In "The Enneads", Plotinus defines ecstasy as the purpose of the soul's existence: the soul is capable of beholding the light of the One and comprehending the meaning of its own existence. Thus, the soul is able to contemplate everything, including itself and even the One in this light: just as we see the sun in its own light, the soul can gaze upon the One only through the light pouring from it. But to behold the One, it is necessary to become blind: when we look at the sun at noon, it blinds us and its disk seems black. ${ }^{11}$ Here is an account by Porphyry (232-301 CE) in his biography of Plotinus:

And this is why to Plotinus-God-like and lifting himself often, by the ways of meditation and by the methods Plato teaches in the Banquet, to the first and all-transcendent God-that God appeared, the God who has neither shape nor form but sits enthroned above the Intellectual-Principle and all the Intellectual-Sphere. 'There was shown to Plotinus, the Term ever near': for the Term, the one end, of his life was to become Uniate, to approach to the God

11 These neo-platonic motives allow, for example, some researchers and admirers to treat Malevich's "Black Square" as "a black icon". We are unable to see what is hidden within the square because we are blind, as if from prolonged gazing at the midday sun. Similarly, Christ's image on many Byzantine icons was painted extremely dark. 
over all: and four times, during the period I passed with him, he achieved this Term, by no mere latent fitness but by the ineffable Act. To this God, I also declare, I Porphyry, that in my sixty-eighth year I too was once admitted and I entered into Union. (Plotinus 1956, p. 17)

In Christian thought, the neo-platonic apophatic theology was expounded by Pseudo-Dionysius the Areopagite. In "The Mystical Theology" he wrote:

Nor can any affirmation or negation apply to it; for while applying affirmations or negations to those orders of being that come next to It, we apply not unto It either affirmation or negation, inasmuch as It transcends all affirmation by being the perfect and unique Cause of all things, and transcends all negation by the pre-eminence of Its simple and absolute nature-free from every limitation and beyond them all. (Dionysius the Areopagite 1997, p. 123)

Now we will explore the thought of a mystic and philosopher who lived half a millennium before Eckhart in a totally different cultural and religious milieu, which makes the similarities between the two authors even more striking. Śankara based his teachings on "The Great Sayings" (māhāvakya) of the Upanishads which express the identity and non-duality of Ätman and Brahman (the Absolute): "that art thou", "not this, not this", "I am Brahman" and "One without a second". Let us try to find in these formulas an intuition related to the thought of the German mystic.

The mahavakyani from Chandogya Upanishad ("Brahman the One, without the second—ekam evadvitiyam Brahma") approves the absolute unity, integrity, and simplicity of reality. Brahman is deprived of distinctions and qualities attributed to him by the mind. Before Śankara, in Chandogya Upanishad, the wise man Uddalaka describes the process of the spontaneous deployment of the One Brahman out of itself. A metaphor used by Uddalaka to describe this process is rivers flowing out of the sea and into the sea:

These rivers, my dear, flow - the eastern toward the east and the western toward the west. They arise from the sea and flow into the sea. Just as these rivers, while they are in the sea, do not know: "I am this river" or "I am that river". (Radhakrishnan 1968, p. 52)

This metaphor depicts Brahman as an absolute integrity in which the distinction of "this" and "that" is impossible. In the primordial absolute reality all distinctions and identities which we assert in everyday life disappear. The main one of those is the personal identity of an individual distinguishing herself from other things of the world and also the cornerstone of those distinctions-the subject-object dichotomy, and the duality (dvaya) of an ordinary consciousness. Brahman is the beginning and the end of reality, and the intention of the practitioner is to see the One in many respects, the reality in beings, in each thing and in himself. Science and art claim and deepen distinctions, whereas mysticism erases distinctions, insisting that there is nothing "second" besides the One and that separate things made out by thetic consciousness are nothing more than an illusion (maya).

The mahavakyani "One without a second" expresses the idea of Brahman without qualities (Nirguna) to whom any definitions are inapplicable ("not that, not that-neti, neti") and who remains self-identical and One eternally. Nirguna Brahman is an indivisible reality, the infinite, a consciousness which lights itself (svaprakāśa), surpassing any binary oppositions. Nirguna Brahman is out of time and out of the world. No predicates and categories and definitions can be said about Brahman except that the spiritual essence Atman is identical to it. "This Brahman is without an earlier and without a later, without an inside and without an outside" (Radhakrishnan 1968, p. 208). In "Atma Bodha", Śankara in his Advaitic interpretation of the Upanishads confirms the inexpressible nature of Brahman: "Realize that to be Brahman which is neither subtle nor gross; neither short nor long; without birth and change; without form, qualities, or colour" (Śan̉karāchārya's Ātmabodha 1947, p. 216).

The reality of Brahman can be described neither as non-existing nor as existing (na asat, no sat). It is Nothingness. From the point of view of "the highest truth" (paramārtha satya), in general, nothing at all occurred with Nirguna Brahman because it could not occur; the creation of the world did not 
happen, and Nirguna Brahman at the level of this highest truth is absolutely identical to pure Atman, or true consciousness (chit). Only in the empirical world is there a plurality of individual souls (jivas), the duality of subject and object; and only in a sensual illusory space is God the creator İśvara, who in Advaita Vedanta is called Saguna Brahman, or Brahman with assigned qualities, real. The researcher E. Torchinov wrote:

Eckhart carries out the difference between the essence of God (Deity) and its nature-God as between the self-contemplation and the contemplated creation. The correlation between the Deity and God in Eckhart is approximately the same as between Nirguna Brahman and İśvara in Advaita Vedanta. (Torchinov 1997, p. 494)

The realization of the identity of Atman and Brahman and de-escalation (nirvritti) of the illusory phenomenal world are possible only in the mystical act of dissolution in Brahman, where any possible division into a subject, object, and process of knowledge disappears. In "Atma Bodha", Śankara states,

Realize that to be Brahman which is Existence-Knowledge-Bliss-Absolute, which is Non-dual, Infinite, Eternal and one and which fills all the quarters-above and below and all that exists between. Realize that to be Brahman which is Non-dual, Indivisible, One, and Blissful and which is indicated in Vedanta as the Immutable Substratum, realized after the negation of all tangible objects. (Śanikarāchārya's Ātmabodha 1947, pp. 213-14)

In Eckhart's treatise "On Detachment" we learn that God is "subtle and simple" and that "Now detachment is so nearly nothing that there is no thing subtle enough to maintain itself in detachment except God alone" (Eckhart 2009, p. 567). But if the vessel, detachment, approaches Nothingness, then Nothingness is similar to it and contains the Deity. Nothingness exceeds the world's plurality, it is the Spirit which comprises everything. Such a characteristic of God reminds one of the apophatic ways in which Nirguna Brahman is described in Advaita Vedanta: Atman-Brahman at the same time is the world, it comprises all things as modifications, and surpasses them. A heuristic formula thanks to which the negative definition of Atman-Brahman is carried out is the above mentioned "not that, not that". Nothingness, to Eckhart, is not only the absence of differences in the primordial integrity; it is also freedom from any predication, from something that it is possible to point to "this" or "that". Eckhart recommends that one consider and understand oneself as pure Nothingness because "the more barely and freely the mind falls on to God and is supported by Him, the more deeply a man is established in God" (Eckhart 2009, p. 508), and "for our whole being depends on nothing but a becoming-nothing" (Eckhart 2009, p. 518).

The perspective of identification and unification with the Deity, which Eckhart quite ecstatically draws, is correlative to the idea of reunion of Atman and Brahman by means of realization of the truth of Makhavakya of Upanishads: "For we should be turned into Him and become fully united with Him, so that His own becomes ours, and ours all becomes His" (Eckhart 2009, p. 509).

According to Aitareya Upanisad (VIII-VII c. BCE), the diverse cognitive activity which is exercised according to their abilities by all living beings conducts them to a source of any ability and to the purpose of any knowledge - to Brahman. The condition of identification of Atman and Brahman is a state where the subject consciousness thematizing the world, that is, knowledge dividing object and subject disappears, and then comes the pure knowledge-a condition of non-separation and simplicity. So, for example, objectivising learning and recitation of sacred texts gradually lead the practitioner to the realization of the non-duality truth hidden in them, and knowledge of this truth is implemented as an ecstatic state, where the thought of Brahman is being Brahman. In Eckhart's doctrine, the Truth is one of the names of God: all truth is true only thanks to this Truth. In the soul of a person the possibility of God-knowledge and God-birth is pledged, whose potentiality is co-substantial to the mystical spark of Deity-Gottheit of the soul.

The act of identification of Atman, the extra-personal spiritual entity present within the person, with the absolute Brahman, is described in Brihadaranyaka Upanishad as an act of recognition: 
Atman recognizes itself ("I am Brahman") and "Therefore it became all" (Radhakrishnan 1968, p. 168). Atman, as well as Brahman, is characterized apophatically: it cannot be described, and concrete acts of knowledge and activity which it causes (breath, speech, thinking) are in essence only "the names of his acts". It is necessary to perceive Atman, as well as the Brahman, as simple and identical to itself-as a trace of all real, and on this trace to find the "lost", that is through the consciousness of non-duality to go back from it to the absolute uniform reality. Besides the identification of Atman and Brahman (positive aspect), it is necessary to conceive Atman negatively as Nothingness: it, as well as Brahman, "not that, not that". Everything that we are able to point to is not Atman. It is not possible to recognize the corporeal or the emotional and mental spheres of the personality as the intimate spiritual source. At the same time, paradoxically, Atman in Chapter I of Brihadaranyaka Upanishad is described as a starting point of a creationistic storyline, whose centre in Chandogya Upanishad was Brahman: "In the beginning, this (world) was just the self, the only" (Radhakrishnan 1968, p. 172).

Atman is the spiritual source which penetrates "the worlds of all beings"; the yogi who knows: "I am Brahman" - everything becomes real, and even gods cannot interfere with him as he becomes their Atman. We see that Brihadarnyaka provides the possibility to interpret Atman as immanent to the world, but at the same time the discursively unconceivable spiritual substance, and (owing to its identity with the Brahman) as transcendental reality: it is both immanent and transcendent. To Eckhart, the Divine Mind comprises all things real, without becoming at the same time anything concrete, that or this. It reminds us of the description of Atman-Brahman in "Atma Bodha": Atman is in everything, the whole world is Atman, there is nothing, except Atman, and the purpose of a yogi is the dissolution of all visible in Atman - the optics shift so that to perceive any "this" as the modification of transcendent "that". The same advice is given by Meister Eckhart in his "The Talks of Instruction": "A man should receive God in all things [ ... ] and in all things seize God in the highest possible way" (Eckhart 2009, p. 493).

In Brihadaranyaka Upanishad, we also find examples of false consciousness which do not lead to moksha. Firstly, it is the dualistic division of an individual reality and the highest reality: "So whoever worships another divinity (than his self) thinking that he is one and (Brahman) another, he knows not" (Radhakrishnan 1968, p. 168). Secondly, it is perceiving the world as an independent entity; its separation from Atman. Even good deeds do not redeem someone who has false consciousness and does not "meditate only on the Self as his (true) world" (Radhakrishnan 1968, p. 171). Only Atman should be worshipped as precious, real, innermost and true.

In Advaita Vedanta, Atman is either polluted by ignorance, feelings, and reason, or clean and spotless. Such division roughly corresponds to Eckhart's "the lowest and highest forces" or "the external" and "internal person". The distinctive feature of the "internal person", as well as of Atman, is that they always remain outside the profane existence, inaccessible for any affects and mental constructs. Just like Shankara's recommendation for contemplation of Atman-Brahman, in "The Talks of Instruction", Eckhart advises the reader to renounce everything that is not Deity: "The more we are owned, the less we own. A man who should have gone out of himself could never fail of God in any works" (Eckhart 2009, p. 499). The renunciation of self that Shankara preaches, at first sight, is of a slightly different sort: it is the refusal to mix upadhi with Atman. Various mental phenomena (pleasure, suffering, anger, fear, desire, boredom) result from a false mixture of the original reality of Atman and its illusory modifications. Atman is not subject to all the listed affects. After the separation of reality per se from the derivative impurity and stratifications, there comes a condition of unshakable rest and bliss-what the Rhine mystic would call detachment, and his neo-platonic predecessors would call reunion with the One.

\section{Conclusions}

Despite numerous differences in the anthropology, epistemology, soteriology, and ontology of Christian and Indian traditions, we can find similar strategies of ontological negativity serving as grounds for mystical experience. Practically all systems of Indian philosophy were projects of 
liberation, i.e., the personal transition from suffering and subjugation into freedom and bliss. The idea of spiritual emancipation is also fundamental to the Christian idea of salvation from sin and achieving blissful unity with God. The apophatic tenets of Christian neo-platonic mystics, such as ideas of the concealment, non-comprehensiveness, and inexpressibility of God as the One and Nothingness, together with the idea of mystical unity with God by means of detachment from all creation and one's own Ego gives us the opportunity for such a comparison.

Author Contributions: Writing—original draft preparation, T.L., D.T.; writing—review and editing, T.L., D.T.; supervision, T.L.; project administration, T.L.

Funding: This research received no external funding.

Conflicts of Interest: The authors declare no conflict of interest.

\section{References}

Aurobindo, Sri. 2006. The Upanishads—II: Kena and other Upanishads. Pondicherry: Sri Aurobindo Ashram.

Bhikkhu, Thānissaro. 2012. Udāna: Exclamations. A Translation with an Introduction \& Notes by Thānissaro Bhikkhu (Geoffrey DeGraff). Available online: https:/ / www.accesstoinsight.org/lib/authors/thanissaro/ udana.pdf (accessed on 1 October 2018).

David Neel, Alexandra. 1937. With Mystics and Magicians in Tibet. Hammondsworth: Penguin Books.

Dionisiy, Areopagit. 2002. Sochineniya. Tolkovaniya Maksima Ispovednika. Saint Petersburg: Aleteya.

Dionysius the Areopagite. 1997. On the Divine Names and the Mystical Theology. Montana: Kessinger Publishing Company.

Eckhart, Meister. 2009. The Complete Mystical Works of Meister Eckhart. New York: O'C. Walshe.

Holt, Linda Brown. 2004. Viewing Meister Eckhart through the Bhagavad Gita. Bloomington: iUniverse.

Joseph, Jijimon Alakkalam, Comparing Eckhartian, and Zen Mysticism. 2015. Buddhist-Christian Studies. Honolulu: University of Hawai'i Press, vol. 35, pp. 91-110.

Keel, Hee-Sung. 2007. Meister Eckhart: An Asian Perspective. Louvain Theological and Pastoral Monographs 36. Louvain: Peeters Press.

Milne, Joseph. 1992. Eckhart and the problem of Christian non-dualism: A comparative study of Eckhart and Advaita Vedanta. Eckhart Review 2: 32-43. [CrossRef]

Otto, Rudolph. 1923. The Idea of the Holy: An Inquiry into the Non-Rational Factor in the Idea of the Divine and Its Relation to the Rational. London: H. Milford, Oxford University Press.

Otto, Rudolf. 2016. Mysticism East and West: A Comparative Analysis of the Nature of Mysticism. Eugene: Wipf and Stock Publishers.

Plotinus. 1956. The Enneads. Translated by Stephen Mckenna. London: Faber and Faber.

Politella, Joseph. 1965. Meister Eckhart and Eastern Wisdom. Philosophy East and West 15: 117-33. [CrossRef]

Radhakrishnan, Sarvepalli. 1968. The Principal Upanishads. London: George Allen \& Unwin Ltd.

Śankkarāchārya's Ātmabodha. 1947. Self-Knowledge. An English Translation of Śankkarāchārya's Ātmabodha with Notes, Comments, and Introduction by Swāmi Nikhilānanda. Mylapore: Sri Ramakrishna Math.

Sells, Michael A. 1994. Mystical Languages of Unsaying. Chicago: University of Chicago Press.

Shah-Kazemi, Reza. 2006. Paths to Transcendence: According to Shankara, Ibn Arabi, and Meister Eckhart. Bloomington: World Wisdom, Inc.

Suzuki, Daisetz Teitaro. 2002. Mysticism: Christian and Buddhist. London and New York: Routledge.

Torchinov, Evgeny Alexeevich. 1997. Religii Mira: Opyt Zapredel'nogo. Saint Petersburg: Peterburgskoye Vostokovedeniye.

Ueda, Shizuteru. 2018. Die Gottesgeburt in der Seele und der Durchbruch zur Gottheit: Die Mystische Anthropologie Meister Eckharts und ihre Konfrontation mit der Mystik des Zen-Buddhismus. München: Verlag Karl Alber.

Zuijderhoudt, C. B. 2008. Meester Eckhart versus Advaita. Amsterdam: Samsara Uitgeverij. 